ISSN 2217-8090

UDK 378:658.8

Original paper/Originalni naučni rad

\section{IMPORTANCE OF MARKETING MIX IN HIGHER EDUCATION INSTITUTIONS}

\author{
Jelena Gajić \\ Singidunum University, Department for Tourism and Hospitality Management, \\ 32 Danijelova Street, Belgrade, Serbia
}

\begin{abstract}
:
Understanding factors and circumstances that create certain market environment conditions is a primary goal of any modern - oriented higher education institution that enables harmonizing the supply with current demands as well as defining appropriate marketing strategies. The process of formulating the strategy of a higher education institution, in addition to reviewing the existing services, includes identifying new opportunities, analyzing relevant competitors and positioning against them and similar. The need for change in marketing strategy, that is market restructuring of a higher education institution, presents a natural consequence of economic oscillations which are the result of market needs and competition dynamics. Continuous monitoring and adjustment of modern developments with the needs of the target market affect the overall perception of service quality and satisfaction of users. Since the choice of marketing strategy involves defining the best ways of achieving the goals, keeping in mind that marketing as a business function, it should contribute to the improvement of educational institutions of governance process, orientation towards the market, or aligning curriculum with the needs of target groups. The Education Reform in Serbia has initiated all educational institutions (private and state) which market-oriented their activities, due to insufficient, inadequate application of current marketing and marketing tools. Using different combinations of marketing mix instruments can lead to achieving competitive advantage in education market. The main role of marketing strategy is to combine competences and other strategies of an educational institution, coordinating the challenges and limitations imposed by its environment and finding the best ways of achieving its mission and vision.
\end{abstract}

\section{Key words:}

marketing,

marketing mix instruments,

higher education,

marketing strategy.

\section{INTRODUCTION}

Intensive development of society and commerce leads to expansion of the service sector, and in such manner it becomes a propagator and dominant force in developed countries, which indicates the necessity of getting to know the significance and specific nature of marketing within the service sector. Considering the education that represents a service activity and its market influenced by various circumstances, educational institution management permanently finds itself facing the pending problem of how to 
accord its offer and marketing strategy with everchanging market requirements. Today, education management is considered a survival condition, as well as a condition of modern society development. Competitive institutions are called only those, which, in the easiest way, adapt to changes of the environment and first adopt innovations.

Application of a marketing strategy enables quality improvement in the system of higher education through synergistic application of marketing mix in order to create a service that corresponds to the expectations of target market and deliver a superior value. Competitive advantage is more and more basing itself on intangible assets (the know-how and expertise of teaching staff, quality of lectures, team work, staff development, etc.), which the competition cannot acquire or successfully imitate in a short period of time. Communication of a higher education institution with target market requires a specific approach, since the decision on the choice of faculty is made once in a life-time. It is defined by time and the decision-making process depends on the family, friends, school and media and therefore it has to be created in a way in which a mixture of marketing communications influences stated segments of target public. Communications, environment, corporate behavior (reputation, innovation, financial power, social responsibility, management quality) shape the image of an educational institution, which, from a long-term aspect, provides competitive advantage and service user loyalty. Also, the price, as one of marketing mix instruments, should, at the same time, be considered as a significant element of educational institution strategic planning, which is often (especially in our background) crucial when deciding which faculty to choose. When defining marketing activities (marketing mix) for educational institutions, special attention must be paid to service distribution, i.e. it is necessary to predefine attractive geographic frame, in which service delivery will be in accordance with the needs and requirements of the target market, respecting the factors (economic, political, sociological, technological, ecological, etc.) acting in a particular background.

The Education Reform in Serbia has prompted all educational institutions to market-orient their business activities, considering insufficient, inadequate application of marketing and marketing instruments so far. Continuous monitoring and harmonization of modern achievements with the needs of the target market influence overall perception of service quality and user satisfaction.

\section{MARKETING IN EDUCATION}

The main goal of marketing in higher education institutions is to define quality education system, market-oriented, whereby one cannot ignore the institution primary role and function, which is to provide a specific type of service of general social benefit, in accordance with its needs. Marketing strategies and activities of business marketing in educational system are limited, much more than in other service and production industries, due to the direct influence of state regulations defining the educational system, with established control mechanisms of accreditation bodies, prescribing the evaluation system, as well as quality control system.

Basic role of a marketing strategy is to combine competence and other strategies of an educational institution, to coordinate challenges and constraints of the environment and to find best ways to realize its missions and visions. Therefore, in order for the organization to be able to meet contemporary requirements of ever-changing business environment, it is necessary that it itself becomes subject to the change and initiate them on its own. (ĐorđevićBoljanović, 2010)

Formulation of a higher education institutional marketing strategy includes decisions about: 1 .The institution's current programs and markets - whether to maintain, build, or drop them. 2. Future new program and market opportunities. 3. Analysis of competitors. 4. Positioning of the institution in relation to competitors. 5. Selection of target markets and designing of the marketing mix. (Kotler and Keller, 2009). Creation of marketing mix service concept needs to be realized in a way that provides synergy between marketing, process management and human resources management. Thus, if the heart of modern strategic marketing, as indicated by Kotler, is comprised of market segmentation, evaluation and selection of target market segment and positioning, i.e. differentiation, then their use in organization pursuits should primarily be oriented towards gaining competitive advantage. This should especially be the case with the offer positioning with the aim of providing a more favorable image on a certain segment in comparison to the present and potential competition.

\section{MARKETING MIX STRATEGY}

Marketing mix has both communicative and operative functions. Communicative function is the 
need to transfer to users the relevancy of services for their needs or preferences. Operative function aims to remove boundaries in transactions or exchange, so that the users, who have opted for that service, can enter the exchange process with minimal effort. Positive synergy comprehends special combination of instruments resulting in extra effectiveness, efficiency or both (Milosavljević and Todorović, 2001). Complexity of all marketing mix instruments of higher education services is shown in Table 1. Instrument synergy is used to realize short-term and long-term goals of higher education institutions.

\begin{tabular}{|c|c|c|c|}
\hline SERVICE & PRICE & DISTRIBUTION & PROMOTION \\
\hline Physical good features & Flexibility & Channel type & Promotion blend \\
\hline Quality level & Price level & Exposure & Salespeople \\
\hline Accessories & Terms & Intermediaries & Advertising \\
\hline Packaging & Differentiation & Outlet location & Sales promotion \\
\hline Warranties & Discounts & Transportation & Publicity \\
\hline Product lines & Allowances & Storage & Internet/Web strategy \\
\hline Brending & & Managing channels & \\
\hline PEOPLE & PHYSICAL EVIDENCE & PROCESS & \\
\hline Employees & Facility design & Flow of activities & \\
\hline - Recruiting & Equipment & - Standardized & \\
\hline - Traininig & Signage & - Customized & \\
\hline - Motivation & Employee dress & & \\
\hline - Rewards & Other tangibles: & Number of steps & \\
\hline - Teamwork & - Reports & - Simple & \\
\hline Customers & - Business cards & - Complex & \\
\hline - Education & - Statements & Customer involvement & \\
\hline - Training & - Guarantees & & \\
\hline
\end{tabular}

Table 1. Expanded Marketing Mix for Services

Source: adapted from Zeithaml et al. (2006)

The fact of a combination of instruments being a complex process is evidenced by a great number of international research studies. With a series of empirical research studies, conducted at the Singidunum University of Belgrade in 2008 and 2009 on target group of students/freshmen (504 first year and 305 second year), we obtained information on marketing application, importance of certain marketing instruments and strategic concepts. In the

decision-making process when estimating alternatives to which faculty to choose, the students have stated: teaching process (41\%), university image (23\%), quality of classes/professor attitudes (16\%), good employment possibilities (13\%), Belgrade as study location (2\%), height of tuition fees (2\%) and installment payment of tuition fee in several months (1\%) (Gajić, 2010) (see Chart 1.).
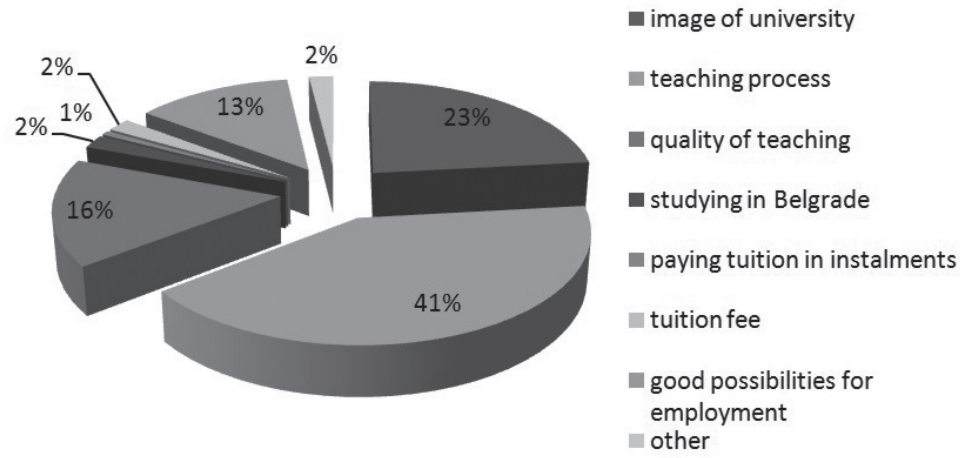

Chart 1. Estimation of student attributes in decision-making process

Source: Gajić, J. (2010) 
Different combinations of marketing mix instruments provide comparative advantage in education market.

\section{EDUCATION AS A PRODUCT}

When it comes to educational offers, Kotler firstly refers to curricula and services.

Offering services involves special challenges because most services are intangible, inseparable, variable, and perishable. Most services do not exist until the service provider performs the service, usually in the presence of the customer. The limitations of services vis-á-vis products also comprise the strengths of services. The professor can expect responses from students - their puzzled looks during a lecture or their vague answers on a quiz - and modify the course content and explanations. (Kostadinović, 2001). The majority of services represent combinations of tangible and intangible elements (they are not completely "clean", mainly containing some physical elements) and services are analyzed on three levels: substantial, tangible and increased. By understanding these levels, marketing managers can shape a service in a way which is attractive to the users. The essence of educational services can be perceived differently, depending on students' expectations and wishes. The essence of a service is not determined only by user experience with that service, rather their understanding/perception of the service without experience. Therefore their decision is also determined by other sources, such as: media, friends, associations etc. (Bruhn and Georgi, 2006).

The essence of a service can (but not necessarily) be the base for the Unique Selling Proposition, and in that case the essence of a service is a base for differentiation and expectation, as well as the user's behavior. In most service industries (educational institutions, airline companies) the essence of a service is a basic, but not also the characteristic/special requirement and in the case of differentiation, additional services or other marketing instruments are used.

The essence of a service is not important only because of its effect on perception and the user's behavior, particularly because it greatly defines the task of other marketing fields. The well-defined essence of a service is a starting point for the systematic and successful marketing service (Bruhn and Georgi, 2006).
The essence of an offer is always limited with some tangible form, even when referring to very intangible services. If we consider students, the essence of a service they are looking for is information/knowledge. The offer tangibility can have a form of an amphitheatre, a classroom, a blackboard, computer or other technical elements. Each of tangible offer characteristics (properties, quality level, packaging and name/brand) is significant, considering its modification in order to make the offer more attractive for the users.

Characteristics are individual components of an offer that can be easily added-on without a change in service style or quality. If a university wishes to increase the number of enrolled students, it should increase concern for them before and after lectures, then increase the number of recreational facilities and introduce free-of-charge courses for students and their parents. The usage of characteristics has a lot of advantages - they are also instruments for differentiating the service from competitive ones. The main advantage is that the characteristics can easily be added-on, but also rejected.

The most important decision, when considering marketing mix in educational institutions is which curriculum and services are to be offered to students, partners and other public. An institutional program/service mix consists of all the programs and services that the institution makes available. For example, many universities offer educational programs (classes, library and information services, computer laboratory, campus lectures, etc.), recreational programs (athletic facilities and clubs, film series, dances, etc.), personal-growth programs and services (counseling center, advisors), curative services (health center), and future-planning programs and services (career counseling, placement services, etc.) (Smart, 2004).

\section{PRICE/TUITION FEE}

The price is one of marketing mix instruments, which, combined with other instruments, should allow the realization of industry goals, the educational institution mission, and the realization of shortterm and long-term industry goals. The price can be viewed as an economic, but also as a psychological factor. From an economic point of view, the price determines income and profit, and psychologically, the price determines values that a product or a service has. It is a quality indicator and equally affects 
the image and the other elements as well. Due to the specificity of the very service, intangibility of price determination requires a special approach, since the price is considered an important strategic element in an attempt of service organization to achieve competitive advantage in the market. The price of a service influences users and informs them not only about the quality they can expect from the service, but also about its costs.

As stated above, the price needs to be considered both from the economic and psychological point of view. The price for users has multiple meanings - it influences their perception and it informs them on what they can expect from the services in terms of quality and costs as well. Administrators-in-charge for price formation in higher education institutions are not often aware of the significance the price has for a user. For instance, the price, formed by some educational institution, does not represent the only cost for the user. The following diagram shows some costs and benefits for the users. In addition to the monetary price, users face other costs, such as costs for effort, physical costs and time costs.
2. the effect of a given pricing policy on enrollment, and

3. the degree to which a particular pricing policy may encourage acceleration.

In addition, the institution must weigh:

- prices charged by comparable competing institutions, and

- the effects of its own price level and price changes on the actions of such competitors.

These considerations provide a basis for setting prices. Pricing decisions should reflect the institution's mission, goals, and priorities (Kotler and Fox, 1995).

Education represents experience that cannot be evaluated before it has been experienced, and the results of attending some educational institution can be evident only after employment and starting a professional carrier. Also, one should bear in mind that the price represents only one marketing mix component, through which user choice is influenced. Potential students, in addition to the tuition fee, will also be interested in educational institution program, educational service quality, location, way of communication and other characteristics. Many students, faculty students and their families are ready to pay a higher price in order to get quality education. When deciding on the educational institution choice, location of the institution and/or its academic prestige can be crucial in making that decision, regardless of tuition fee price. Consideration and use of the price as a marketing instrument cannot be observed separately, rather only as a part of overall marketing strategy.
Figure 1. The consumer's costs and benefits

Source: Kotler and Fox (1995)

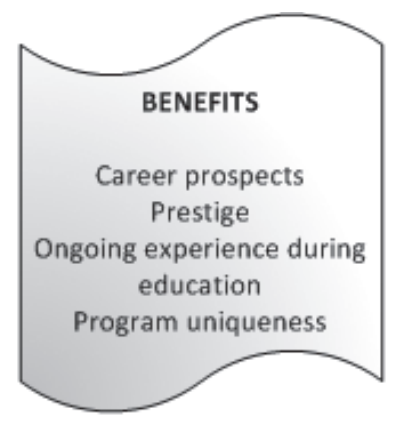


Effective communication comprehends that a university understands students' needs and wishes. The university should have the "know-how" in coding a message, which is reflected in the way students are to decode it. It needs to send out the message via effective medium, communicating with the target group. It also needs to develop a feed-back channel, in order to the "know-how" target group reacted to the message.

The communications planning flow should begin with considering the target audience and work backward to the communicator. The marketing communicator must make the following decisions (Kotler and Fox, 1995):

1. identify the target audience,

2. clarify the sought response,

3. develop a message,

4. choose the medium or media,

5. select source attributes, and

6. collect feedback.

These planning steps are essential for effective communications, whether advertising, marketing publications, or public relations are used.

In order for a university to be successful, it has to find a way to promote its products and services. Higher education institutions should effectively communicate with their products and public. It's not enough only to have good curricula and competitive prices, but the service user and all the interested need to be informed of the goals, activities, offer of the institution and motivated to join and become users. That communication takes place in several forms. Faculties, schools and other educational institutions are always (speaking for themselves) sending out a message to the public on their existence regardless of whether they formally have a communication program or not. Also, the institution must determine and get a comprehensive insight into information needs of internal environment (faculty, staff, existing students and others within the internal environment, etc.).

In order to use appropriate communication channels it is necessary to perform grouping of marketing communications: personal sale, sale improvement, advertising, publicity, public relations, and sponsorships, direct marketing, etc. According to Kotler and Fox (1995), most educational institutions use public relations, marketing publications and, to a lesser extent, advertising. The best definition of today's modern practice has been given by professors Lawrence V. Long and Vincent Hazelton, who have described public relations as "communicative management function through which the organizations adapt, change or maintain their environment in order to reach their goals" (Vilkoks et al., 2006). Public relations should encourage open two-way communication and mutual understanding, whereby in such process the organization itself changes its positions and behavior and not only the target group (Živković, 2011).

Whatever is the format of information, honesty is, to a reasonable extent, the best solution. Potential students want honesty, which maximizes efficient choice, regardless of how they are developed or changed in enrollment process (Canterbury, 1999). Of course, we should not neglect modern communication media, i.e. social networks, the aim of which is to communicate their way into a trusting relationship between the institution and its users. The research has shown that people usually become motivated to share important information with their friends on the network, because they expect their experience to be helpful or of any use to someone.

Higher education institutions communicate with various groups (students, parents, donors, employees and community), whose interests vary. Schools, universities and other educational institutions are interested in achieving understanding and sympathy of the public. The public/partners are not related only to the educational institution, they are connected also among each other. The public, particularly, can affect attitudes and behavior of other members of external environment through an institution. Their enthusiasm will additionally motivate the teachers, professors, to improve their services. In addition, alumni can be generous donors and promoters of a faculty, and in that way students influence the attitudes and behavior of the remaining part of university public/ partners.

In marketing we distinguish between internal and external information search. Since the choice of faculty does not exist as previous experience, the internal way is insufficient and it is resorted to external informing.

External comprehends gathering information from various external channels (friends, advertising, informers, etc.) and the results of mentioned research indicate that the majority of subjects have 
made their decisions on the recommendation of a friend 72\% (Gajić, 2010) (Chart 2).

The media, as a source of information has had least influence on forming attitudes, and personal sources have proven themselves to be the most dominant.

The research results (Gajić, 2010) in relation to efficiency of communicative instruments indicate that the personal contact has highest influence to future users of educational services. Considering the importance of the decision to be made, $83 \%$ of students find the university presentation in secondary schools best way of promotion, $9 \%$ stated internet, 5\% television and 1\% newspaper (Gajić, 2010) (Chart 3.).

Development and application of efficient promotion strategy is a complex task. There is no unique approach that guarantees success, but key activities in promotion management must comprise, except the analysis of potential students, identification of their needs, as well as the analysis of competitive promotion activities.

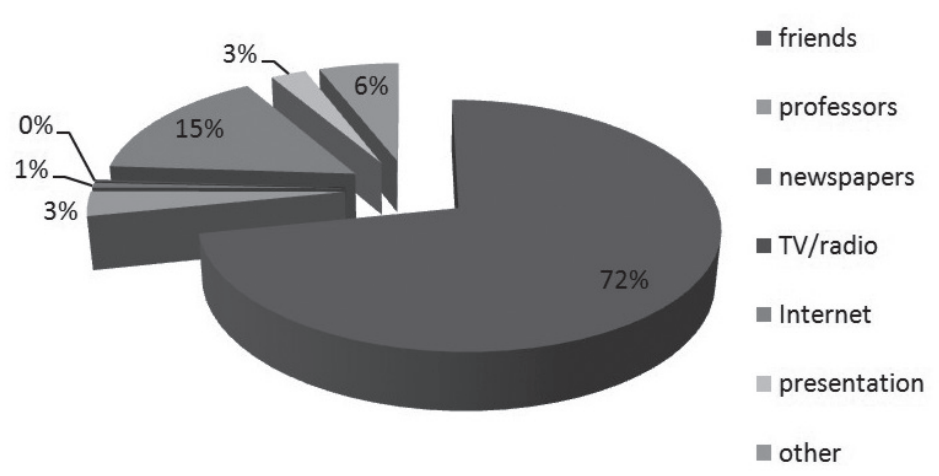

Chart 2. Sources of information

Source: Gajić, J. (2010)

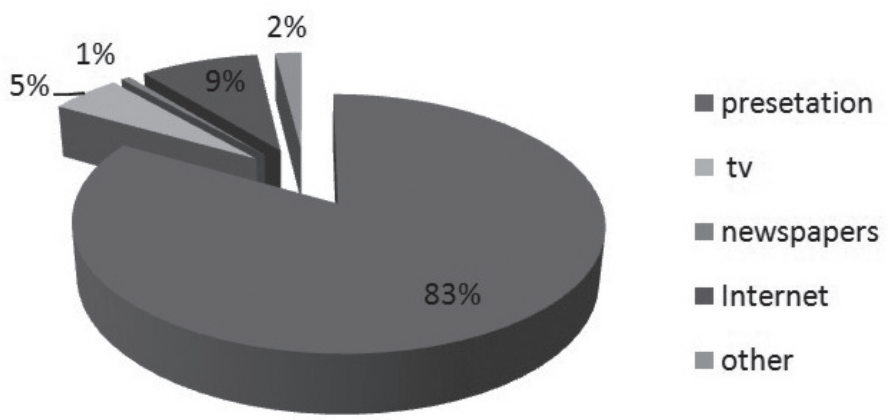

Chart 3. Student positions on communication instruments efficiency

Source: Gajić, J. (2010)

\section{EDUCATIONAL SERVICE DISTRIBUTION}

The main question concerning the delivery of educational services is "How to make programs of higher education institution more accessible and acceptable for students?" When it comes to the location of the institution, we should bear in mind multiple meanings of that term. First, the location can refer to the place where the institution is (e.g. University of New York is located in New York, Singidunum University in Belgrade ). Then, it can refer to the characteristics of the area in which the insti- tution is located. Location can also have a relative meaning, i.e. it can be viewed in relation to where current and future students and high school students live. Most educational institutions have already had its buildings in one or more places. Usually, when an educational institution starts to think about improving efficiency of its work, that is sought to be realized within the existing facilities. The institutions, in the first place, consider how to attract the users, to the existing buildings, while the idea of getting the clients more familiar with their offer is accepted slower. 
Delivering programs and services is as important as designing them because delivery system determines who can benefit from the universities' programs and services. Since educational services usually cannot be "stored up", educational institutions need to consider how to make their services as convenient as practicable to their target markets in terms of both locations and schedules. Increased convenience and quality may include implementation of distance education and/or the use of new technologies (Kotler and Fox, 1995).

Universities should take into account physical buildings, including appearance, signage, functionality and atmosphere of service space, as well as messages that the building and the environment send to the visitors, employees and students.

\section{PEOPLE IN EDUCATIONAL INSTITUTIONS}

People, as a key instrument in educational process, are constituted of curricular, extracurricular staff, students and other partners in the environment, doing business with the university. Curricular and extracurricular staff together participates in service delivery and influence perception of service users. All the students that participate in service delivery influence the decisions of a service user, depending on the nature of that service. How the participants dress, their personal opinion and behavior influence the perception of a service user. Those, who provide service or persons in personal contact with future service users, are highly important, considering that direct contact is dominant because the one, who delivers the service, creates the service. Research has shown that contribution of these agents can be the key in a success of a service institution.

\section{Staff}

Internal marketing refers to management of necessary actions, in order to provide understanding of all organization members and in order for their roles to be accepted in implementation of marketing strategies. This means that everyone in vertical hierarchy from rectors, deans to lower qualified staff, have to be aware of the significance of the role they perform, as well as of their contribution to marketing strategy implementation. All employees have to recognize intentions and requests of the students, as well as specific nature of services, shaped with mar- keting concept. Staff motivation is improved with training and education. To maintain and develop effective, friendly and informative internal channel communication and interaction among employees and departments, it is necessary to have open communication through the institutions. Communication is also important in development of internal relations in the institution. Even the best intentions are useless if they are not communicated in a proper way (Dobrijević, 2011). The research has shown that there is a positive relation between a successful internal communication and positive attitude of employees towards the company (Dobrijević, 2011).

Staff motivation represents a significant element in marketing plan implementation and internal marketing. People work in order to meet physical, psychological and social needs. To satisfy employees in marketing, managers have to detect their needs and develop motivational methods that would enable meeting their needs (Vilijams, 2010). It is very important for the motivational plan to be ethic and comprehensible to the staff. Generally, to improve motivation of employees, higher education institutions can find out what the employees think, feel and want through internal investigations. Organizations can motivate their staff either financially, promotion-wise, using flexible benefit programs, etc. It is possible for the motivation to be only for individuals, using special methods, based on individual system of values. Managers can reward their employees with money, plus extra benefits, promotions, non-monetary rewards etc.

Success of a higher education institution depends on quality and dedicated staff. With the purpose of creating the very same, it is necessary to provide motivational working conditions (academic freedom, adequate financial compensation, etc.). Successful academic systems must offer to their teaching staff adequate working and compensation conditions, possibility of carrier building with appropriate guarantees for long-term specialization and employment. Without these conditions, an academic institution cannot be successful nor think about world-wide reputation.

In order for modern universities to be competitive in the market, they need to be marketing-oriented, get a thorough insight into all types of users, types of potential students and their needs. It is necessary to establish the decision-making process based on quality, values or cost-effectiveness for the students and on the persons who find important their carrier, social recognition or leisure. Successful 
educational institutions in their strategic planning rely on investigations of market segments of future students. Identifying target market is the starting point in this process and the university can opt for either mass marketing (if it ignores the differences among potential students or confronts them) or target marketing (if it respects the differences in future students).

For some universities, marketing approach creates a value between university partners (stakeholders). University partners are future students, existing students, alumni, staff (ex-students), donors and all that provide financial support. For state universities, partner list is complemented with taxpayers, legislation and sometimes even with general public.

The three fundamental freedoms of the university - to teach what they want; to whom they want; and in the way they want - have constituted the key weaponry in the armory of higher education institutions. They have used them as benchmarks for measuring progress and indeed estimating the extent of acceptable change in the sector. Society has now changed. No longer are universities seen as the most powerful organization in the society. The corporate world has taken over and has begun to exert an influence on other forms of organizations in a way never imagined in the past. Higher education now finds itself in a situation where it increasingly has much to learn from the outside world and indeed relies heavily on others to maintain its viability. One of the new lessons universities are learning from the business and commercial world today is how to develop a customer perspective (Maringe and Gibbs, 2009).

In order to determine statisfaction of students at the beginning of the academic year and the results of how much students are satisfied with the first classes, confirms positive impression of offered service (43\%), 36\% are moderately satisfied, $13 \%$ of subjects believe the classes could be better and $3 \%$ of subjects are not satisfied with offered service (Gajić, 2010) (Chart 4.).

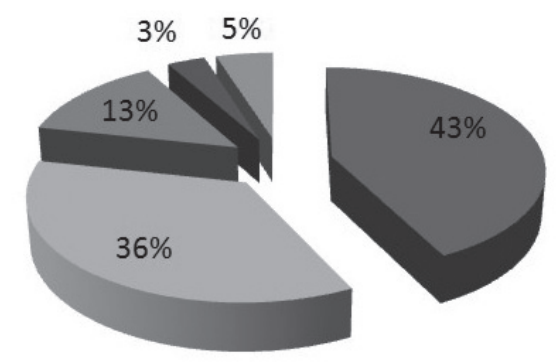

\author{
nery satisfied \\ moderately satisfied \\ dissatisfied \\ very dissatisfied \\ no answer
}

Chart 4. Satifaction of students with first classes quality Source: Gajić, J. (2010)

The results confirm that marketing activities cannot be effectively implemented without cooperation with the staff. The staff is the key element in productivity growth, providing quality service to users and gaining competitive advantage. The quality represents service performance level perceived by the students. Service quality is especially important and can be very variable, depending on skills, motivation and mood of service deliverer (professors and student service staff).

\section{Students}

Process of selecting a faculty is a key decision in the life of every individual and requires information on alternatives, as well as on how those alternatives are ranked in relation to concrete situations.
Many decisions about educational choice (and about making significant donations) are high-involvement decisions. High personal involvement usually is present when one or more of the following conditions exist (Kotler and Fox, 1995):

1. The consumer's decision will reflect upon his or her self-image and could have long-term consequences.

2 The cost to carry out the decision involves major personal or economic sacrifies.

3. The personal and social risks of making a wrong decision are perceived as high.

4. There is considerable reference-group pressure to make a particular choice or to act in a particular way, and the target consumer is strongly motivated to meet the expectations of these reference groups. 
For many students, "the process of studying not only represents the acquisition of certain skills and theoretical knowledge. It is also related to personal growth and social development" (Jurkowitsch et al. 2006).

An improper decision can be brought on the basis of the tendency for conformism or so-called fitting in - to be closer to home, minimize costs of all kinds, opt for prestigious names. The research shows that student services, counseling, parents, potential students and higher education researchers indicate the importance of fitting in (Canterbury, 1999).

Success, quality and total outcome of university experience determine to which extent a service user is satisfied (Maringe, 2005).

When it comes to the increase of student's freedom of choice, research studies treating student behavior when making a choice show that we cannot presume the students will make a rational choice of institution and field of study, even if we put them in the position to choose. Choice of type and con- crete institution is influenced by a complex combination of personal expectations, motivations and aspirations, and all of them influenced by the family, peers, relatives, media, teachers, idols, etc. (Gajić, 2010).

Special consideration should be given to the influence of parents in the process of choosing a faculty and the effect of that process to the family. Necessity of discussion within the family, as primary reference group, is caused by several factors: socioeconomic status, the fact whether the child is the first in the family enrolling a faculty, parents' education and geographic region, among other, but none of these elements look like those referring to other decision processes.

Having in mind that influence of reference groups on decision-making process is very important and that people as consumers take on certain behavior standards under their influence, in the above-mentioned research (Gajić, 2010) there are the following results (Chart 5).

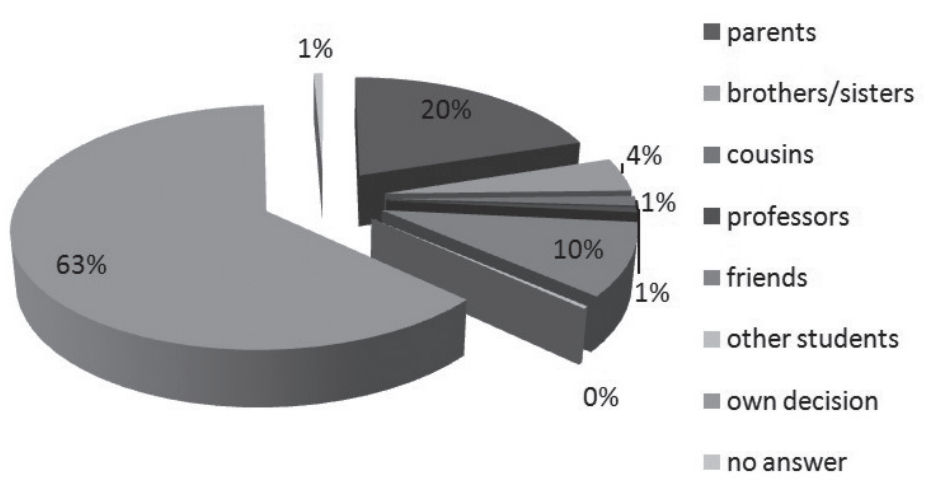

Chart 5. Influence of reference groups in decision-making process

Source: Gajić, J. (2010)

In order for us to determine which of the reference groups has the key influence on students in the process of making such an important decision, our results have confirmed that the family, as a primary reference group, affected $20 \%$ of subjects. However, a rather interesting data is that as many as $63 \%$ of students have responded they have made the decision on their own. Hypothetically speaking, their profile says they can be classified as routine users, who know what they want and have no need for additional information. According to numerous research studies, it is believed that the highest influence of commercial propaganda is possible exactly on that target group, especially having in mind that younger population is characterized by sophisticated information gathering processes, most of them electronic, so they are often called natural techno profiles. They particularly have a visual communication, resulting in a real fear that this could be reflected in their verbal abilities in the future.

Student satisfaction is a subjective estimation of an individual and total experience they have in relation to service characteristics, as well as between what they have actually received and the perception of the gap among received and expected benefits. Academic and pedagogical quality of classes, university infrastructure, and administrative staff service quality should be carefully organized and supervised. 


\section{Teaching process}

Observing a service process, education falls into a category, which comprehends treatment of mental stimuli that refer to intangible actions oriented towards conscience of people. In this process, a student needs to be mentally present, but can be located either at the very location where the service is created (amphitheatre or classroom) or at a distant location connected over telecommunication networks.

Considering the characteristics of a service process, managers must have a clear insight in the benefits of educational services, understand the students, and formulate channel distribution strategies and shape service providing system (using information technologies). Educational services are personal and characterized by intensive, intellectual, emotional and/or physical participation of students in a service process. Services are often realized in a number of steps, which, basically, constitute the very service process. Production and consumption of educational services take place simultaneously and students' participation in it is rather important. They evaluate service quality, hence the shaping of the service process - detailed planning on how to provide a service - is vital to maintain (improve) educational service quality. The process is so important that some authors describe it as a real essence of service (Senić and Senić, 2008).

At the university there is clear differentiation among services realized in direct contact with the users and various service processes taking place outside of direct contact. From the aspect of a university, there can be several functions and services involved in the process of creating an educational service, but the students (public) see them as a single integral process or system. Also, a student (service user) is an integral part of service system model, within the organization and he/she interacts with other parts of the organization in the service process representing a resource for service production.

Successful schooling would have to be founded on teaching (didactic) principles. All teaching systems, methods, forms and all instruments/means of work rely on them. Without teaching (didactic) principles, in other words, every system, method, form and every mean of work would be incomplete. Teacher's skill in preparation of systems, methods, forms and means of work with teaching principles would be, as a result, productive and the students would learn with quality. (Simeunović, 2004).
Marketing concept is a way that enables educational institutions to provide their services efficiently with continuous communication both with the target market and within the organization. But marketing concept and culture must be, first of all, clear to all employees, i.e. it needs to take hold within an educational institution.

\section{Service environment}

Service environment gives an external picture on what kind of service a user can expect and helps employees and users to make service transaction in an easier way. Also, service environment for the employees and users indicates desired roles, behavior and transactions in the service process. Using service environments, an institution is differentiated in comparison with the competition and sends out the message to the segment destined.

Only a strategic approach to understanding the role and importance of service environment allows service offer to be on the appropriate level and to positively influence perceived quality. Service environment represents service package affecting creation of expectations, i.e. represents a visual metaphor of intangible service. It is also an element in image building and in that sense it sends a message, draws attention and provokes effects/reactions in users (Veljković, 2009). Service environment elements, influencing the users, include both facility exterior and interior shown in Table 2.

Web presentations and virtual display of environment through the internet are newer forms of communication, which institutions use in order to make their service more tangible before and after purchase (Zeithaml et al., 2006).

Physical environment can play a significant role in students' choice. Since, it is one of the most important decisions in life of young people and their families, that has caused modern educational institutions to offer virtual tours, all with the purpose of providing future users with a closer insight in the environment, before making a decision which educational institution to enroll at. Internet technology allows the institutions to make their service and environment more familiar to the users. Tangible image on the web creates expectations in users, posing standards of service delivery and it is very important for the services to meet those expectations. Presentations and virtual tours in the internet also should support the position of the service/brand, as well as to be consistent with other marketing messages. 


\begin{tabular}{lll}
\hline Facility exterior & Facility interior & Other tangilbles \\
\hline Exterior design & Interior design & Business cards \\
Signage & Equipment & Stationary \\
Parking & Signage & Billing statements \\
Landscape & Layout & Reports \\
Surrounding environment & Air quality/temperature & Employee dress \\
& & Uniforms \\
& & Brochures \\
& & Web pages \\
\end{tabular}

Table 2. Elements of Phisical Evidence

Source: Zeithaml et al. (2006)

\section{CONCLUSION}

Modern universities gain competitive advantage primarily through attractive curricula, renowned teaching staff, which applies modern technologies in performing teaching process and through quick adaptation and reaction to changes or new needs of a background.

In addition to consideration of students' needs, higher education institutions must also take into consideration wishes of other groups such as staff, alumni, parents and the state. A great challenge for an educational institution is to synchronize interests of different groups, and to maintain balance in order to satisfy interests of the society and service users at the same time.

Higher education institutions in Serbia have understood the importance of marketing application, as well as its contribution to improvement of many aspects of university activities, such as internal and external communication, improvement in the process of educational service delivery, financing issue and determining height of tuition fee, teaching process quality, but in the first place user satisfaction.

Analyzing certain marketing mix instruments we come to a conclusion that the communication with higher education target market requires a specific approach and that successful higher education institutions with good image should build a synergetic communication system which would make realization of communication goals possible. The The research results show that the most efficient instrument in the communication with target public is the presentation in schools and, we can conclude that this is the best way of persuasive propaganda which creates students' opinions in a most direct way. Price is also a good indicator of quality and it plays an important role when creating the image of a higher education institution. Consequently, it is considered at the same time as a significant element in strategic planning of an educational institution when deciding which faculty to choose. Since the quality of service is of particular importance and it can be rather variable depending on skills, motivation and mood of the deliverer, in that same sense the first encounter with the service can significantly influence formation of the overall satisfaction. The satisfaction of students with the first classes speaks of a positive impression of the offered service. It can be concluded that universities realize competitive advantage improving intangible assets.

When it comes to marketing strategy concept for emerging markets, there must be a lot of uncertainties in terms of speed and development, in relation to competition behavior, with appropriate combination of characteristics of marketing mix instruments. Only the one, which has developed a system of monitoring and deciphering signals of a background, can have a timely reaction to new opportunities and risks. New technologies create new markets and new possibilities improve marketing mix, develop and introduce new products/services into the market. New ways of communication and service processes, only with the help of new technologies, allow more efficient delivery of educational services. 


\section{REFERENCES}

Bruhn, M., Georgi, D. (2006) Service Marketing. New Jersey: Prentice Hall.

Canterbury, R.M. (1999) Higher education marketing: a challenge. Journal of College Admission. 165 (3), 22-30.

Dobrijević, G. (2011) Poslovno komuniciranje i pregovaranje. Belgrade: Singidunum University. (in Serbian)

Đorđević-Boljanović, J. (2010) Organizaciona kultura kao faktor uticaja na efektivnost programa menadžementa znanja. Singidunum review. 5 (2), 163-171. (in Serbian)

Gajić, J. (2010) Marketing strategija u visokom obrazovan$j u$. Thesis, PhD. Singidunum University, Belgrade. (in Serbian)

Jurkowitsch, S., Vignali, C., Kaufmann, H.R. (2006) A student satisfaction model for Austrian higher education providers considering aspects of marketing communications. Innovative Marketing. 2 (3), 9-23.

Kostadinović, D. (2007) Uloga i značaj kvaliteta u oblasti obrazovanja. Pedagoška stvarnost. 53 (7-8), 599-612. (in Serbian)

Kotler, P., Keller, K.L. (2009) Marketing Management. 13th ed. New Jersey: Prentice Hall.

Kotler, P., Fox, K. (1995) Strategic Marketing for Educational Institutions. New Jersey: Prentice-Hall.

Maringe, F. (2005) Interrogation the crisis in the higher education marketing: CORD model, International Journal of Educational Management. 19 (7), 564-578.
Maringe, F., Gibbs, P. (2009) Marketing Higher Education, Theory and Practice. London: McGraw Hill.

Milosavljević, M., Todorović, J. (2001) Marketing strategija. Belgrade: Faculty of Economy, University of Belgrade. (in Serbian)

Senić, R., Senić, V. (2008) Menadžment i marketing usluga. Kragujevac: Faculty of Economy, University of Kragujevac. (in Serbian)

Simeunović, Ž. (2004) Interesantnost i atraktivnost nastave kao nastavni princip. Pedagogija. 59 (2), 59-67. (in Serbian)

Smart, J.C. (2004) Higher Education: Handbook of Theory and Research, Volume XIX. Dordrecht: Kluwer Academic Publishers.

Veljković, S. (2009) Marketing usluga. 3rd ed. Belgrade: Faculty of Economy, University of Belgrade. (in Serbian)

Vilkoks, L.D., Kameron, T.G., Olt, H.F., Ejdžin, K.V. (2005) Odnosi sa javnošću. Belgrade: Faculty of Economy, University of Belgrade. (in Serbian)

Vilijams, C. (2010) Principi menadžmenta. Belgrade: Data status. (in Serbian)

Zeithaml, A.V., Bitner, J.M., Gremler, D.D. (2006) Services Marketing. New York: McGraw Hill.

Živković, R. (2011) Ponašanje i zaštita potrošača. Belgrade: Singidunum University. (in Serbian)

\section{ZNAČAJ MARKETING MIKSA U VISOKOOBRAZOVNIM INSTITUCIJAMA}

\section{Rezime:}

Razumevanje faktora i okolnosti koji kreiraju tržišnu atmosferu je primarni cilj savremeno orijentisane visokoobrazovne institucije, kako bi uskladila ponudu sa aktuelnom tražnjom i definisala odgovarajuću marketing strategiju. Proces formulisanja strategije visokoobrazovnih institucija, pored sagledavanja postojećih usluga, predstavlja i identifikovanje novih mogućnosti, analizu i pozicioniranje prema relevantnoj konkurenciji i sl. Potreba za promenom marketing strategije, odnosno tržišnog restrukturiranja visokoobrazovne institucije javlja se kao prirodna posledica pulsiranja sistema privređivanja koja je zasnovana na dinamici tržišnih potreba i konkurencije. Kontinuirano praćenje i usklađivanje savremenih dostignuća sa potrebama ciljnog tržišta utiču na ukupnu percepciju kvaliteta usluge i na satisfakciju korisnika. Shodno tome, izbor marketing strategije podrazumeva definisanje najboljih načina ostvarivanja ciljeva, imajući u vidu da marketing kao poslovna funkcija treba da doprinese poboljšanju upravljačkih procesa obrazovne institucije, orijentisane ka tržištu, odnosno usklađivanjem nastavnih programa sa potrebama ciljnih grupa i tržita rada. Reforma obrazovanja u Srbiji inicirala je sve obrazovne institucije (privatne ali i državne) da tržišno orijentišu svoje poslovne aktivnosti, s obzirom na nedovoljnu i neadekvatnu dosadašnju primenu marketinga i marketing instrumenata. Pomoću različitih kombinacija instrumenata marketing miksa mogu se ostvariti komparativne prednosti na tržištu obrazovanja. Osnovna uloga marketing strategije je da kombinuje kompetentnosti i druge strategije obrazovne institucije, usklađuje izazove i ograničenja iz okruženja i pronalazi najbolje načine za ostvarivanje misije i vizije.

\section{Ključne reči:}

marketing, instrumenti marketing miksa, visoko obrazovanje, marketing strategija.

Received: January 16th, 2012

Correction: February 21st, 2012

Accepted: March 10th, 2012 